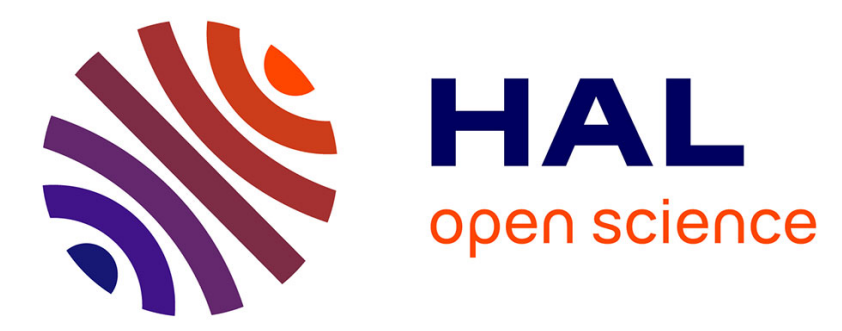

\title{
Inventing Narratives of the Anthropocene: Microclimate Machines and Arts \& Sciences Installations Jean-Marc Chomaz
}

\section{To cite this version:}

Jean-Marc Chomaz. Inventing Narratives of the Anthropocene: Microclimate Machines and Arts \& Sciences Installations. MM '19: The 27th ACM International Conference on Multimedia, 2019, Nice France, France. pp.1665-1666, 10.1145/3343031.3355513 . hal-02938386

\section{HAL Id: hal-02938386 https://hal.science/hal-02938386}

Submitted on 17 Nov 2021

HAL is a multi-disciplinary open access archive for the deposit and dissemination of scientific research documents, whether they are published or not. The documents may come from teaching and research institutions in France or abroad, or from public or private research centers.
L'archive ouverte pluridisciplinaire HAL, est destinée au dépôt et à la diffusion de documents scientifiques de niveau recherche, publiés ou non, émanant des établissements d'enseignement et de recherche français ou étrangers, des laboratoires publics ou privés. 


\title{
Inventing Narratives of the Anthropocene: Microclimate Machines and Arts \& Sciences Installations
}

\author{
Jean-Marc Chomaz \\ Laboratoire d'Hydrodynamique \\ CNRS/École Polytechnique \\ chomaz@ladhyx.polytechnique.fr
}

\begin{abstract}
Since the creation of the Laboratoire d'Hydrodynamique (LadHyX) of the CNRS and the École Polytechnique, I have been involved as a researcher and artist in "arts \& sciences" projects in all disciplines (circus, theatre, design, contemporary art, music, etc.). My approach tries to give direct access to an imaginary using scientific language and concepts not to demonstrate, but to make sense.
\end{abstract}

The works I have created alone or jointly with other artists such as Ana Rewakowicz and Camille Duprat, Anaïs Tondeur, Aniara Rodado, the duets Evelina Domnitch Dmitry Gelfand, HeHe, or within the Labofactory collective founded with Laurent Karst and François-Eudes Chanfrault, are not intended to show or demonstrate scientific phenomena, to provide formal evidence or to reveal established facts. Rather, they suggest a different point of view, a destabilizing transgression, an uncomfortable comparison, a bodily experience, a metaphor for physics that would use the scientific imagination to reinvent our perception of the world and question the truth in its relativity and in all its fragility.

These shared adventures have led me to realize that my intention is closely linked to deeper meaning and commitment. The human species, which, on a geological scale, should have remained an ephemeral and marginal event, is confronted with a deadly threat directly linked to its own action and its casual use, without verbalization and questioning, of science and technology. The fascination that science exerts on everyone's mind, starting with scientists themselves, remains extremely powerful, as evidenced by media coverage of the likely observation of the Higgs Boson or the black hole in the centre of the giant Messier 87 galaxy. Science therefore does not need to be re-invested but to be reinvested by humans, in order to allow new stories to emerge in thought and speech and to constitute a modern "song of gesture", entirely devoted to sustainable actions on a global scale and to the emergence of ethical paths of thought, generally accepted.

Scientists are beginning to understand that science and the scientific approach itself may be powerless to solve or even grasp the reality and meaning of, for example, climate change or the new frontiers that today's questions of life and consciousness represent.

Permission to make digital or hard copies of part or all of this work for personal or classroom use is granted without fee provided that copies are not made or distributed for profit or commercial advantage and that copies bear this notice and the full citation on the first page. Copyrights for third-party components of this work must be honored. For all other uses, contact the Owner/Author.

MM '19, October 21-25, 2019, Nice, France.

(C) 2019 Copyright is held by the owner/author(s).

ACM ISBN 978-1-4503-6889-6/19/10.

DOI: https://doi.org/10.1145/3343031.3355512
Much of my scientific research and work combining art and science focuses on the question of climate change, and more specifically on how to predict, analyse and understand the scope, in the current state of knowledge, of the notion of the anthropocene; the controversial use of this term, which alone serves as a manifesto, calls into question the impact and ethics of mankind and requires a commitment both individually and collectively to define and build a new pact, an updated and shared new deal.

Such global problems and challenges are beyond the realm of science alone, which is designed to divide a complex and sensitive problem into several small isolated systems, until it reaches a stage where the issue can be the subject of a laboratory experiment, computer study or modeling in a scientist's brain. Science was never designed to rebuild the fragile and complex system as a whole. We need a different protocol, another approach and a new analytical framework to address the challenges posed by the multiple, complex and transdisciplinary phenomena embedded in the concept of the anthropocene.

Art and science encompass all the performances and narratives necessary for this confrontation, question our beliefs and observations, but also the nature, legitimacy and ethics of our scientific practice without the usual restrictions imposed on critical thinking by an almost sacred and therefore impossible to question protocol of proof. Once this judicious common vision has been constructed through art, scientific narratives and narratives resulting from the association of science with art, it should permeate all the actions of all individuals and communities and, secondarily, undoubtedly contribute to defining and attributing to science a more reasonable path to follow, or at the very least to bringing back to it the possibility of critical thinking.

The possibility for arts \& sciences research and creation to contribute to such a critical thinking and to construct alternative form of narratives of the anthropocene, will be illustrated on several examples of microclimate machines and installations.

\section{BIOGRAPHY}

Jean-Marc Chomaz is an artist physicist, director of research at the CNRS, professor at the École Polytechnique, co-bearer of the Carasso Foundation's arts \& sciences chair. He co-founded the Hydrodynamics laboratory of CNRS-École Polytechnique (LadHyX), which he chaired from 1990 to 2012, the laboratory of excellence Systems and Engineering of Paris Saclay University (LaSIPS), which he chaired from 2011 to 2019, and La Diagonale 
Paris Saclay in 2012. He has supervised $31 \mathrm{PhDs}$ and co-authored 200 articles in peer-reviewed journals. His awards and distinctions include: CNRS silver medal, Grand Prix Ampère of the Academy of Sciences, fellow of the American Physical Society and of the EuroMech. His research focuses on the dynamics of soap films, biomechanics, instability theory, geophysical fluids and arts \& sciences. As an artist, he is the co-founder with Laurent Karst of the collective Labofactory exhibited internationally: Infraespace, fluxus, Exoplanet, 2080, Redshift, Sky, Soleil Irrésolu, Black out...He has created with other artists more than 20 installations, Luminiferous drift, Absynth, Basic Transmutation, EP=EPR, the Nephelograph - mist impression, Memory of the ocean...

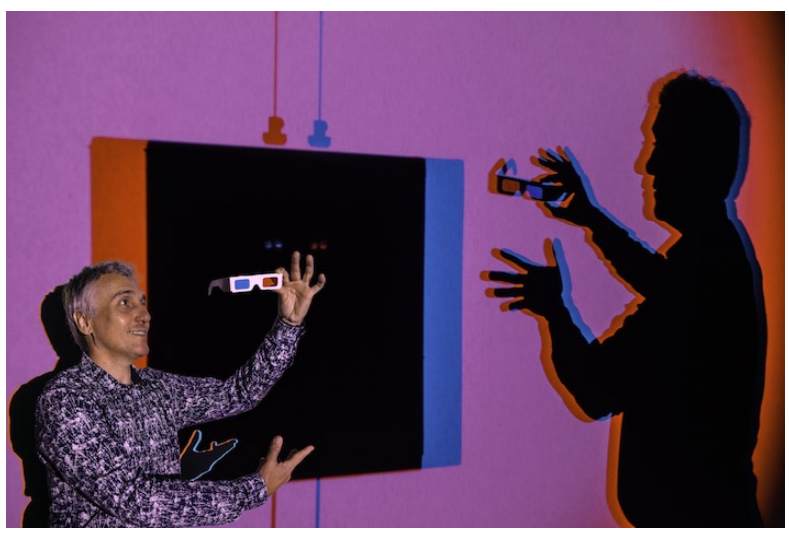

Figure 1: Installation Redshift $n^{\circ} 2$ : Malevich dialogue with Takis created for the Black2 exhibition at the rez Hodynka gallery in Moscow 2015 and presented here at the Salon des Réalités Nouvelles, Paris 2015 (Photo Brigite Cavanagh) 